\title{
Synthesis and Biological Analysis of Thiotetra(ethylene glycol) monomethyl Ether-Functionalized Porphyrazines: Cellular Uptake and Toxicity Studies
}

\author{
Sangwan Lee, ${ }^{1}$ Benjamin J. Vesper, ${ }^{2,3}$ Hong Zong, ${ }^{1}$ Neal D. Hammer, ${ }^{2,3}$ Kim M. Elseth, ${ }^{2,3}$ \\ Anthony G. M. Barrett, ${ }^{4}$ Brian M. Hoffman, ${ }^{1}$ and James A. Radosevich ${ }^{2,3}$ \\ ${ }^{1}$ Department of Chemistry, Northwestern University, 2145 Sheridan Road, Evanston, IL 60208, USA \\ ${ }^{2}$ Center for Molecular Biology of Oral Diseases, College of Dentistry, University of Illinois at Chicago, 801 S. Paulina Street, \\ Chicago, IL 60612, USA \\ ${ }^{3}$ Jesse Brown VAMC, 820 South Damen Avenue, Chicago, IL 60612, USA \\ ${ }^{4}$ Department of Chemistry, Faculty of Natural Sciences, Imperial College London, Faculty Building, South Kensington Campus, \\ London SW7 2AZ, UK \\ Correspondence should be addressed to James A. Radosevich, jrados@uic.edu
}

Received 29 May 2007; Revised 20 July 2007; Accepted 6 August 2007

Recommended by Michael J. Cook

\begin{abstract}
The porphyrazines (pzs), a class of porphyrin analogues, are being investigated for their potential use as tumor imaging/therapeutic agents. We here examine six peripherally-functionalized $\mathrm{M}\left[\mathrm{pz}\left(\mathrm{A}_{n} \mathrm{~B}_{4-n}\right)\right]$ pzs with $n=4,3$, or 2 (in a trans conformation) and $\mathrm{M}$ $=\mathrm{H}_{2}$ or $\mathrm{Zn}$, where $\mathrm{A}$ is an $\left[\mathrm{S}\left(\left(\mathrm{CH}_{2}\right)_{2} \mathrm{O}\right)_{4} \mathrm{Me}\right]_{2}$ unit and $\mathrm{B}$ is a fused $\beta, \beta^{\prime}$-diisopropyloxybenzo group. Cell viability/proliferation assays and fluorescence microscopy were carried out in both tumor and normal cells. Dark toxicity studies disclosed that four of the compounds exhibited toxicity in both normal and tumor cells; one was nontoxic in both normal and tumor cells, and one was selectively toxic to normal cells. Additionally, three of the pzs showed enhanced photo-induced toxicity with these effects in some cases being observed at treatment concentrations of up to ten-fold lower than that needed for a response in Photofrin. All six compounds were preferentially absorbed by tumor cells, suggesting that they have potential as in vitro diagnostic agents and as aids in the isolation and purification of aberrant cells from pathological specimens. In particular, two promising diagnostic candidates have been identified as part of this work.
\end{abstract}

Copyright (C) 2008 Sangwan Lee et al. This is an open access article distributed under the Creative Commons Attribution License, which permits unrestricted use, distribution, and reproduction in any medium, provided the original work is properly cited.

\section{INTRODUCTION}

Porphyrin antitumor agents have been widely studied in recent years, especially in the area of photodynamic therapy (PDT), where the development of the clinically used porphyrin, haematoporphyrin derivative ( $\mathrm{HpD}$, or Photofrin), has garnered significant interest $[1,2]$. However, limitations in the design, synthesis, and biological properties of Photofrin have led to the development of many secondgeneration PDT agents, including a number of porphyrin derivatives [3-9]. One such class of compounds being investigated as an alternative is the porphyrazines (pzs), porphyrin analogues in which the meso $(\mathrm{CH})$ groups are replaced by nitrogen atoms linking the pyrrole rings (Scheme 1 , Section 3), thereby resulting in compounds with chemical and physical properties distinct from those of the porphyrins [10]. The presence of the meso-nitrogen atoms results in the pzs possessing intense long-wavelength absorbance and emission bands, photophysical properties that are intrinsically superior to those of the porphyrins. Furthermore, the porphyrazines are prepared by the templated cyclization of maleonitrile derivatives, while porphyrins are synthesized by the condensation of aldehyde and pyrrole derivatives. This difference allows pzs to be readily prepared with $S, N$, or O heteroatoms attached to the macrocycle core, while porphyrins cannot. These heteroatom substituents enable the photophysical properties of the pzs to be tuned such that they exhibit optimal near-IR absorbance and emission in the 700$900 \mathrm{~nm}$ window, and allow for tuning of their singlet oxygen quantum yields from essentially off to on-characteristics 
which make the pzs attractive candidates for biomedical applications [11-14].

Because of the novelty of these compounds, initial biocompatibility studies involving the pzs have focused upon determining how specific pz structures selectively alter biological functions $[15,16]$, leading to the establishment of "structure-function rules," which will ultimately be used to predict future biologically active pzs. To this end, we recently reported the biological activity of a suite of three anionic $\mathrm{H}_{2}\left[\mathrm{pz}\left(\mathbf{A}_{n} \mathbf{B}_{4-n}\right)\right]$ pzs, in which $n=4,3$, or 2 (trans), $\mathbf{A}$ was an $[\mathrm{S}-\mathrm{R}]_{2}$ unit with $\mathrm{R}=\left(\mathrm{CH}_{2}\right)_{3} \mathrm{CO}_{2}{ }^{-}$, and $\mathbf{B}$ was a fused $\beta, \beta$-dialkoxybenzo group. These three anionic compounds showed a systematic increase in toxicity as $n$ (and in turn, the number of R groups) was increased, and one $\mathrm{pz}(n=2)$ was found to be selectively toxic to tumor cells. Herein we similarly describe the biocompatibility of a group of $\mathrm{M}\left[\mathrm{pz}\left(\mathrm{A}_{n}\right.\right.$ $\left.\mathrm{B}_{4-n}\right)$ ] pzs, where $\mathrm{M}=\mathrm{H}_{2}$ or $\mathrm{Zn}, n=4,3$, or 2 (trans), $\mathrm{A}$ is an $[\mathrm{S}-\mathrm{R}]_{2}$ unit with $\mathrm{R}=\left[\left(\mathrm{CH}_{2}\right)_{2} \mathrm{O}\right]_{4} \mathrm{Me}$, and $\mathbf{B}$ is again a fused $\beta, \beta^{\prime}$-dialkoxybenzo group (5-10, Scheme 1). ${ }^{1}$

As with the aforementioned anionic porphyrazines, the pzs examined here, with thiotriethoxy(ethoxy)methyl groups appended to their periphery, allow us to study the biological effect of a specific functional group. By varying $n$, we can simultaneously vary the core $\mathrm{pz}$ structure and the number of appended $\mathrm{R}$ groups, resulting in each compound possessing slightly different chemical and physical properties, thereby impacting the biological effects of each.

This study also marks the first biocompatibility experiments involving metallated pzs. As previously reported, the singlet oxygen quantum yields $\left(\Phi_{\Delta}\right)$ of the free-base $\left(\mathrm{H}_{2}\right)$ pzs increase systematically as $n$ is decreased; the same trend is true for metallated pzs, but the presence of $\mathrm{Zn}$ in the $\mathrm{pz}$ core increases the value of $\Phi_{\Delta}$ approximately five-fold over that of the analogous $\mathrm{H}_{2}$ pzs [12]. Herein we report the concentration/time-dependent cytotoxicity and phototoxicity measurements, and present confocal fluorescence microscopic visualization, for pzs 5-10 in A549 tumor and WI-38 VA13 normal cells.

\section{MATERIALS AND METHODS}

\subsection{Chemical reagents and instrumentation}

All chemicals were purchased from Aldrich Chemical Company "Wis, USA" and used as received. Baxter silica gel (60 ; 230-400 mesh) was used for column chromatography. A Hewlett-Packard HP8452A diode-array spectrophotometer was used to record electronic absorption spectra, and electronic emission spectra were recorded using a Photon Technology International QM2 fluorescence spectrometer. ${ }^{1} \mathrm{H}$ and ${ }^{13} \mathrm{C}$ NMR spectra were obtained using a Varian Inova $500 \mathrm{MHz}$ spectrometer. Electrospray ionization mass

\footnotetext{
${ }^{1}$ To aid the reader, the compounds in this report have been numbered sequentially 1-10. We note, however, that in the Master Compound Log in the lab of B.M.H., the compound numbers are as follows: $5=174 ; 6=$ $175 ; 7=176 ; 8=177 ; 9=178 ; 10=179$.
}

spectra (ESI-MS) were recorded using a Finnegan LCQ Advantage mass spectrometer, and matrix-assisted laser desorption ionization-time of flight mass spectra (MALDI-TOFMS) were recorded using a PE Voyager DE-Pro MALDITOF mass spectrometer; $\alpha$-cyano-4-hydroxycinnamic acid was used as the matrix for MALDI-TOF experiments.

\subsection{Porphyrazine synthesis}

Disodium 1,2-dicyano-1,2-ethenedithiolate $\left(\mathrm{Na}_{2} \mathrm{MNT}\right)$ [17] and 1-imino-4,7-bis(1-methylethoxy)-1H-isoindolin3-amine (diiminoisoindoline, 1) [11] were prepared as previously reported. During the purification of each pz, distinct bands were observed and pooled together during column chromatography; collected fractions were monitored by UV-visible spectroscopy. Each pz was prepared as a $5 \mathrm{mM}$ working stock solution in dimethyl sulfoxide (DMSO) for use in the tissue culture experiments.

\subsection{2-\{2-[2-(2-Methoxyethoxy)ethoxy]ethoxy\} ethyl-4-methylbenzenesulfonate (3)}

Sodium hydroxide ( $12 \mathrm{~g}, 0.3 \mathrm{~mol})$ dissolved in water $(55 \mathrm{~mL})$ and tetra(ethylene glycol) monomethyl ether (2) (41.7 g, $0.2 \mathrm{~mol}$ ) in THF ( $55 \mathrm{~mL})$ were placed in a flask, and the mixture was stirred and cooled in an ice bath. To the mixture was added dropwise $p$-toluenesulfonyl choride $(41.9 \mathrm{~g}, 0.22 \mathrm{~mol}$ ) in THF $(65 \mathrm{~mL})$ over 30 minutes with continuous stirring and cooling of the mixture below $5^{\circ} \mathrm{C}$. The solution was stirred an additional 2 hours at $\sim 0-5^{\circ} \mathrm{C}$, at which time the mixture was poured into ice water $(200 \mathrm{~mL})$ and extracted twice with $\mathrm{CH}_{2} \mathrm{Cl}_{2}(200 \mathrm{~mL})$. The combined organic extract was washed twice with water and once with a saturated $\mathrm{NaCl}$ solution (brine), and then dried over $\mathrm{Na}_{2} \mathrm{SO}_{4}$. After evaporation of the solvent, the resulting residue was purified by chromatography on silica gel ( $4 \% \mathrm{MeOH}$ in $\mathrm{CH}_{2} \mathrm{Cl}_{2}$ eluant) to yield the tosylate $3(63 \mathrm{~g}, 87 \%)$ as a colorless viscous oil: ${ }^{1} \mathrm{H}$ NMR $\left(500 \mathrm{MHz}, \mathrm{CDCl}_{3}\right) \delta 2.43\left(\mathrm{~s}, 3 \mathrm{H}, \mathrm{ArCH}_{3}\right), 3.35$ (s, 3H, $\left.\mathrm{OCH}_{3}\right), 3.52\left(\mathrm{t}, 2 \mathrm{H}, \mathrm{CH}_{2}\right), 3.50-3.60\left(\mathrm{~m}, 10 \mathrm{H}, \mathrm{CH}_{2}\right), 3.67(\mathrm{t}$, $\left.2 \mathrm{H}, \mathrm{CH}_{2}\right), 4.14\left(\mathrm{t}, 2 \mathrm{H}, \mathrm{CH}_{2}\right), 7.33(\mathrm{~d}, 2 \mathrm{H}, \mathrm{ArH}), 7.78(\mathrm{~d}, 2 \mathrm{H}$, $\mathrm{ArH}) ;{ }^{13} \mathrm{C}$ NMR $\left(125 \mathrm{MHz} \mathrm{CDCl}_{3}\right) 21.8,59.1,68.8,69.4$, 70.6, 70.8, 71.2, 71.6, 71.9, 72.2, 128.1, 130.0, 133.1, 145.0; ESI-MS $(m / z)$ calculated for $\mathrm{C}_{16} \mathrm{H}_{27} \mathrm{O}_{7} \mathrm{~S}[\mathrm{M}+\mathrm{H}]^{+} 363.44$, found 363 .

\section{4. bis $\{2-\{2-[2-(2-M e t h o x y e t h o x y) e t h o x y] e t h o x y\}$ ethylthio\} maleonitrile (4)}

$\mathrm{Na}_{2} \mathrm{MNT}$ (7.45 g, $0.04 \mathrm{~mol}$ ) was treated with two equivalents of $3(30.45 \mathrm{~g}, 0.084 \mathrm{~mol})$ in acetone $(80 \mathrm{~mL})$ at reflux under a nitrogen atmosphere for 12 hours. The solvent was then removed under reduced pressure, and the resulting residue was purified by chromatography on silica gel $(4 \% \mathrm{MeOH}$ in $\mathrm{CH}_{2} \mathrm{Cl}_{2}$ eluant) to yield $4(13.40 \mathrm{~g}, 64 \%)$ as a viscous yellow oil: ${ }^{1} \mathrm{H}$ NMR $\left(500 \mathrm{MHz}, \mathrm{CDCl}_{3}\right) \delta 3.30\left(\mathrm{t}, 4 \mathrm{H}, \mathrm{CH}_{2}\right), 3.56$ $\left(\mathrm{s}, 6 \mathrm{H}, \mathrm{OCH}_{3}\right), 3.50\left(\mathrm{t}, 4 \mathrm{H}, \mathrm{CH}_{2}\right), 3.53\left(\mathrm{t}, 4 \mathrm{H}, \mathrm{CH}_{2}\right), 3.58(\mathrm{t}$, $\left.4 \mathrm{H}, \mathrm{CH}_{2}\right), 3.62 \sim 3.64\left(\mathrm{~m}, 8 \mathrm{H}, \mathrm{CH}_{2}\right), 3.65\left(\mathrm{t}, 4 \mathrm{H}, \mathrm{CH}_{2}\right), 3.74$ $\left(\mathrm{t}, 4 \mathrm{H}, \mathrm{CH}_{2}\right) ;{ }^{13} \mathrm{C} \mathrm{NMR}\left(125 \mathrm{MHz}, \mathrm{CDCl}_{3}\right) 21.8,59.1,68.8$, 
69.4, 70.7, 70.8, 71.3, 71.7, 72.0, 73.2, 128.1; ESI-MS $(\mathrm{m} / \mathrm{z})$ calculated for $\mathrm{C}_{22} \mathrm{H}_{39} \mathrm{~N}_{2} \mathrm{O}_{8} \mathrm{~S}_{2}[\mathrm{M}+\mathrm{H}]^{+}$523.69, found 523 .

\section{5. $2,3,7,8,12,13,17,18-o c t a k i s\{2-\{2-[2-(2-$ Methoxyethoxy)ethoxy]ethoxy\} ethylthio $-21 H, 23 H$-porphyrazine (5)}

Mg turnings $(0.1 \mathrm{~g}, 4 \mathrm{mmol})$ and $\mathrm{I}_{2}\left(0.01 \mathrm{~g}, 4 \times 10^{-5} \mathrm{~mol}\right)$ in $n$ - $\mathrm{PrOH}(50 \mathrm{~mL})$ were heated at reflux for 24 hours under $\mathrm{N}_{2}$ to prepare $\mathrm{Mg}(\mathrm{OPr})_{2}$. $\mathrm{MNT}\left[\mathrm{S}\left(\mathrm{C}_{2} \mathrm{H}_{4} \mathrm{O}\right)_{4} \mathrm{Me}\right]_{2}$ (4) (5.23 g, $0.01 \mathrm{~mol}$ ) was added, and the reaction was heated at reflux for 7 hours. The yellow reaction mixture gradually turned green. After 2 hours, the reaction mixture was a deep blue color. Heating and stirring were continued for a total 7 hours after which the solvent was removed under reduced pressure. The resulting residue was dissolved in $\mathrm{CH}_{2} \mathrm{Cl}_{2}(20 \mathrm{~mL})$. TFA $(2 \mathrm{~mL})$ was slowly added, and the solution was stirred for 1 hour. After dilution in $\mathrm{CH}_{2} \mathrm{Cl}_{2}(100 \mathrm{~mL})$, the mixture was washed 4 times with a large amount of water to remove any residual TFA, dried over $\mathrm{Na}_{2} \mathrm{SO}_{4}$, and rotary evaporated. The resulting residue was purified via column chromatography $\left(4 \% \mathrm{MeOH}\right.$ in $\mathrm{CH}_{2} \mathrm{Cl}_{2}$ eluant) to produce 5 (628 mg, 12\% yield) as a dark blue solid: UV-vis $\left(\mathrm{CH}_{2} \mathrm{Cl}_{2}\right)$ $\lambda_{\max }(\log \varepsilon) 360$ (4.66), 502 (2.23), 640 (3.10), 710 (3.99) nm; ${ }^{1} \mathrm{H}$ NMR $\left(500 \mathrm{MHz}, \mathrm{CDCl}_{3}\right.$ ) $\delta-1.13$ (br s, $\left.2 \mathrm{H}, \mathrm{NH}\right), 3.32$ (s, $\left.24 \mathrm{H},-\mathrm{OCH}_{3}\right), 3.40\left(\mathrm{t}, 16 \mathrm{H}, \mathrm{CH}_{2}\right), 3.55 \sim 3.59(\mathrm{~m}, 64 \mathrm{H}$, $\left.\mathrm{CH}_{2}\right), 3.65\left(\mathrm{t}, 16 \mathrm{H}, \mathrm{CH}_{2}\right), 3.99\left(\mathrm{t}, 16 \mathrm{H}, \mathrm{CH}_{2}\right), 4.28(\mathrm{t}, 16 \mathrm{H}$, $\left.\mathrm{CH}_{2}\right) ;{ }^{13} \mathrm{C} \mathrm{NMR}\left(125 \mathrm{MHz}, \mathrm{CDCl}_{3}\right)$ 34.76, 59.23, 70.68, 70.72, 70.74, 70.77, 71.11, 72.09, 140.56; MALDI-TOF-MS $(m / z)$ calculated for $\mathrm{C}_{88} \mathrm{H}_{155} \mathrm{~N}_{8} \mathrm{O}_{32} \mathrm{~S}_{8}[\mathrm{M}+\mathrm{H}]^{+}$2093.72, found 2093.66; calculated for $\mathrm{C}_{88} \mathrm{H}_{154} \mathrm{~N}_{8} \mathrm{NaO}_{32} \mathrm{~S}_{8}[\mathrm{M}+\mathrm{Na}]^{+}$ 2115.71, found 2116.48 .

\section{6. $\quad\{2-\{2-[2-(2-M e t h o x y e t h o x y) e t h o x y] e t h o x y\}$ ethylthio\} porphyrazines 6 and 7}

Mg turnings $(0.3 \mathrm{~g}, 12 \mathrm{mmol})$ and $\mathrm{I}_{2}\left(0.03 \mathrm{~g}, 1.2 \times 10^{-4} \mathrm{~mol}\right)$ in $n-\mathrm{PrOH}(150 \mathrm{~mL})$ were heated at reflux for $24 \mathrm{~h}$ under $\mathrm{N}_{2}$ to prepare $\mathrm{Mg}(\mathrm{OPr})_{2}$. $\mathrm{MNT}\left[\mathrm{S}\left(\mathrm{C}_{2} \mathrm{H}_{4} \mathrm{O}\right)_{4} \mathrm{Me}\right]_{2}$ (4) (5.23 g, $0.01 \mathrm{~mol}$ ) and diiminoisoindoline (1) (5.23 g, $0.02 \mathrm{~mol})$ were added, and the reaction was heated at reflux for 7 hours, during which time the solution went from orange to blue-black. The solvent was removed under reduced pressure, and the residue was dissolved in $\mathrm{CH}_{2} \mathrm{Cl}_{2}(30 \mathrm{~mL})$. TFA $(3 \mathrm{~mL})$ was slowly added, and the solution was stirred for 1 hour. After dilution in $\mathrm{CH}_{2} \mathrm{Cl}_{2}(200 \mathrm{~mL})$, the mixture was washed 4 times with a large amount of water to remove any residual TFA, dried over $\mathrm{Na}_{2} \mathrm{SO}_{4}$, and rotary evaporated. The resulting residue was purified via column chromatography $(4 \%$ $\mathrm{MeOH}$ in $\mathrm{CH}_{2} \mathrm{Cl}_{2}$ eluant) to yield 6 (260 mg, 4.3\%) as a dark blue solid and 7 (477 mg, 6.2\%) as a dark green solid, as well as trace amounts of 5 .

\subsection{9,22-bis(1-Methylethoxy)-4,5,9,10,14,15- hexakis $\{2-\{2-[2-(2-m e t h o x y e t h o x y) e t h o x y]-$ ethoxy ethylthio $\}-23 H, 25 H$-porphyrazine (6)}

UV-vis $\left(\mathrm{CH}_{2} \mathrm{Cl}_{2}\right) \lambda_{\max }(\log \varepsilon) 350$ (4.61), 658 (3.82), 702 (4.35), 744 (sh) nm; ${ }^{1} \mathrm{H}$ NMR $\left(500 \mathrm{MHz}, \mathrm{CDCl}_{3}\right) \delta-0.20$ (br s, 2H, NH), 2.02 (d, 12H, $-\mathrm{CHMe}_{3}$ ), 3.69 (s, 18H, $\left.\mathrm{OCH}_{3}\right), 3.76 \sim 3.79\left(\mathrm{~m}, 48 \mathrm{H}, \mathrm{CH}_{2}\right), 3.84 \sim 3.87(\mathrm{~m}, 24 \mathrm{H}$, $\left.\mathrm{CH}_{2}\right), 4.02\left(\mathrm{t}, 4 \mathrm{H}, \mathrm{CH}_{2}\right), 4.17\left(\mathrm{t}, 4 \mathrm{H}, \mathrm{CH}_{2}\right), 4.19(\mathrm{t}, 4 \mathrm{H}$, $\left.\mathrm{CH}_{2}\right), 4.39\left(\mathrm{t}, 4 \mathrm{H}, \mathrm{CH}_{2}\right), 4.46\left(\mathrm{t}, 4 \mathrm{H}, \mathrm{CH}_{2}\right), 4.51(\mathrm{t}, 4 \mathrm{H}$, $\mathrm{CH}_{2}$ ), 5.49 (sept, 2H, $-\mathrm{CHMe}_{2}$ ), 7.87 (s, 2H, ArH); ${ }^{13} \mathrm{C} \mathrm{NMR}$ $\left(125 \mathrm{MHz}, \mathrm{CDCl}_{3}\right)$ 22.3, 22.4, 22.7, 22.9, 29.9, 34.7, 34.8, $34.9,36.5,59.2,70.6,70.7,70.8,71.1,71.2,72.1,72.7,119.6$, $126.5,138.4,138.8,141.9,150.5$; ESI-MS $(\mathrm{m} / z)$ calculated for $\mathrm{C}_{80} \mathrm{H}_{133} \mathrm{~N}_{8} \mathrm{O}_{26} \mathrm{~S}_{6}[\mathrm{M}+\mathrm{H}]^{+}$1815.36, found 1815.70; calculated for $\mathrm{C}_{80} \mathrm{H}_{132} \mathrm{~N}_{8} \mathrm{NaO}_{32} \mathrm{~S}_{8}[\mathrm{M}+\mathrm{Na}]^{+}$1837.34, found 1837.76.

\subsection{1,4,13,16-tetrakis(1-Methylethoxy)-8,9,20,21- tetrakis $\{2-\{2-[2-(2-m e t h o x y e t h o x y) e t h o x y]-$ ethoxy ethylthio $\}-25 H, 27 H$-dibenzo[b,I] porphyrazine (7)}

UV-vis $\left(\mathrm{CH}_{2} \mathrm{Cl}_{2}\right) \lambda_{\max }(\log \varepsilon) 342$ (4.80), 654 (5.41), 712 (2.20), $796(4.31) \mathrm{nm} ;{ }^{1} \mathrm{H}$ NMR $\left(500 \mathrm{MHz}, \mathrm{CDCl}_{3}\right) \delta-0.44$ (br s, $2 \mathrm{H}, \mathrm{NH}$ ), 2.26 (d, 24H, $\mathrm{CHMe}_{2}$ ), 3.91 (s, 24H, $\mathrm{OCH}_{3}$ ), $3.93 \sim 3.96\left(\mathrm{~m}, 24 \mathrm{H}, \mathrm{CH}_{2}\right), 4.08 \sim 4.14\left(\mathrm{~m}, 16 \mathrm{H}, \mathrm{CH}_{2}\right)$ $4.18\left(\mathrm{t}, 8 \mathrm{H}, \mathrm{CH}_{2}\right), 4.24\left(\mathrm{t}, 8 \mathrm{H}, \mathrm{CH}_{2}\right), 4.77\left(\mathrm{t}, 8 \mathrm{H}, \mathrm{CH}_{2}\right), 5.28$ (sept, $4 \mathrm{H}, \mathrm{CHMe}_{2}$ ), 7.56 (s, 4H, ArH); ${ }^{13} \mathrm{C} \mathrm{NMR}(125 \mathrm{MHz}$, $\mathrm{CDCl}_{3}$ ) 22.7, 23.0, 35.1, 59.1, 70.6, 70.7, 70.8, 71.0, 71.1, 71.3, 72.0. 72.5, 118.5, 128.3, 138.7, 149.8; ESI-MS $(\mathrm{m} / z)$ calculated for $\mathrm{C}_{72} \mathrm{H}_{111} \mathrm{~N}_{8} \mathrm{O}_{20} \mathrm{~S}_{4}[\mathrm{M}+\mathrm{H}]^{+}$1536.96, found 1536.63; calculated for $\mathrm{C}_{72} \mathrm{H}_{110} \mathrm{~N}_{8} \mathrm{NaO}_{20} \mathrm{~S}_{4}[\mathrm{M}+\mathrm{Na}]^{+} 1558.95$, found 1558.70 .

\subsection{Zn porphyrazines 8,9 , and 10}

The three metallated pzs were each prepared analogously to zinc pzs previously described [11]. A solution of zinc chloride $(20.4 \mathrm{mg}, 0.15 \mathrm{mmol})$ in methanol $(10 \mathrm{~mL})$ was added to a solution of metal-free porphyrazine $(0.05 \mathrm{mmol})$ in $\mathrm{CH}_{2} \mathrm{Cl}_{2}(30 \mathrm{~mL})$. The reaction mixture was heated to reflux for 30 minutes or until zinc insertion was completed, as monitored by spectrophotometry. The reaction mixture was diluted with $\mathrm{CH}_{2} \mathrm{Cl}_{2}(60 \mathrm{~mL})$, washed with water to remove excess zinc chloride, dried with $\mathrm{Na}_{2} \mathrm{SO}_{4}$, and evaporated to dryness under vacuum. The resulting residue was purified by chromatography on silica gel $\left(4 \% \mathrm{MeOH}\right.$ in $\mathrm{CH}_{2} \mathrm{Cl}_{2}$ eluant) to yield the desired $\mathrm{Zn}$ porphyrazine in quantitative yield.

\subsection{0. $2,3,7,8,12,13,17,18$-octakis $\{2-\{2-[2-(2-$ Methoxyethoxy)ethoxy]ethoxy ethoxy\} ethylthio-porphyrazine zinc(II) (8)}

UV-vis $\left(\mathrm{CH}_{2} \mathrm{Cl}_{2}\right) \lambda_{\max }(\log \varepsilon) 378$ (4.62), 672 (4.67) nm; MALDI- TOF-MS $(m / z)$ calculated for $\mathrm{C}_{88} \mathrm{H}_{153} \mathrm{~N}_{8} \mathrm{O}_{32} \mathrm{~S}_{8} \mathrm{Zn}$ $[\mathrm{M}+\mathrm{H}]^{+}$2157.12, found 2157.32; calculated for $\mathrm{C}_{88} \mathrm{H}_{152} \mathrm{~N}_{8} \mathrm{NaO}_{32} \mathrm{~S}_{8} \mathrm{Zn}[\mathrm{M}+\mathrm{Na}]^{+}$2179.10, found 2179.24. 


\subsection{9,22-bis(1-Methylethoxy)-4,5,9,10,14,15- hexakis $\{2$-\{2-[2-(2-methoxyethoxy)ethoxy]- ethoxy\} ethylthio $-23 \mathrm{H}, 25 \mathrm{H}$-porphyrazine $\operatorname{zinc}($ II) (9)}

UV-vis $\left(\mathrm{CH}_{2} \mathrm{Cl}_{2}\right) \lambda_{\max }(\log \varepsilon) 362$ (4.60), 618(sh), 676 (4.69), $706(\mathrm{sh}) \mathrm{nm}$; ESI-MS $(\mathrm{m} / z)$ calculated for $\mathrm{C}_{80} \mathrm{H}_{131} \mathrm{~N}_{8} \mathrm{O}_{26} \mathrm{~S}_{6} \mathrm{Zn}$ $[\mathrm{M}+\mathrm{H}]^{+}$1878.73, found 1878.60 .

\subsection{2. $\mathrm{Zn}$ (II) 1,4,13,16-tetrakis(1-methylethoxy)- 8,9,20,21-tetrakis $\{$ 2-\{2-[2-(2-methoxyethoxy)- ethoxy]ethoxy ethylthio $\}-25 \mathrm{H}, 27 \mathrm{H}$ - dibenzo[b,I]porphyrazine (10)}

UV-vis $\quad\left(\mathrm{CH}_{2} \mathrm{Cl}_{2}\right) \quad \lambda_{\max } \quad\left(\begin{array}{lllll}\log & \varepsilon\end{array}\right) 352 \quad(4.64), \quad 666$ (4.73), 761(4.64) nm; ESI-MS $(m / z)$ calculated for $\mathrm{C}_{72} \mathrm{H}_{109} \mathrm{~N}_{8} \mathrm{O}_{20} \mathrm{~S}_{4} \mathrm{Zn}[\mathrm{M}+\mathrm{H}]^{+}$1600.34, found 1599.63.

\subsection{Cell culture and cell lines}

All media and supplements were purchased from Invitrogen "Calif, USA" except where noted. Phosphate-buffered saline (PBS) solution was prepared by adding $\mathrm{Na}_{2} \mathrm{HPO}_{4} \bullet 7$ $\mathrm{H}_{2} \mathrm{O}$ (54.0 g), $\mathrm{KH}_{2} \mathrm{PO}_{4}(5.0 \mathrm{~g}), \mathrm{KCl}(5.0 \mathrm{~g})$, and $\mathrm{NaCl}$ $(200.0 \mathrm{~g})$ to $25 \mathrm{~L}$ of distilled water. A $2.0 \mathrm{~g} / \mathrm{L}$ solution of 3-[4,5-dimethylthiazol-2-yl]-2,5-diphenyltetrazolium bromide (MTT) in PBS was prepared and sterile filtered $(0.2 \mu \mathrm{m}$ pore size $)$ prior to use in the cytotoxicity assays. Haematoporphyrin derivative $(\mathrm{HpD}$, or Photofrin; QLT Phototherapeutics, Inc. "Vancouver, BC, Canada") was used as a positive control in the phototoxicity assays; concentrations of $\mathrm{HpD}$ were calculated using an assigned molecular weight of 600 .

The following cell lines were utilized in this study: A549 (human lung adenocarcinoma), WI-38 VA13 (SV40 transfected fibroblast-like human embryonic cell line), five human head and neck squamous cell carcinomas (SCC016, SCC040, SCC056, SCC114, SCC116), and three human breast adenocarcinomas (BT-20, T-47D, and MCF-7). All cell lines were obtained from American Type Culture Collection "Va, USA." The A549 and T-47D cell lines were maintained in RPMI 1640 media supplemented with 10\% fetal calf serum heat inactivated at $56^{\circ} \mathrm{C}$ for 30 minutes, $2 \mathrm{mM}$ L-Glutamine, $100 \mu \mathrm{g} / \mathrm{mL}$ Streptomycin, $100 \mathrm{U} / \mathrm{mL}$ Penicillin, and $2.5 \mathrm{mcg} / \mathrm{mL}$ Amphotericin B solution. All other cell lines were maintained in minimum essential medium (MEM) with Earle's salts supplemented with 10\% fetal calf serum heat inactivated at $56^{\circ} \mathrm{C}$ for 30 minutes, $2 \mathrm{mM} \mathrm{L}$ Glutamine, $100 \mu \mathrm{g} / \mathrm{mL}$ Streptomycin, $100 \mathrm{U} / \mathrm{mL}$ Penicillin, and $2.5 \mathrm{mcg} / \mathrm{mL}$ Amphotericin B solution, as well as $100 \mu \mathrm{M}$ MEM nonessential amino acids and $1 \mathrm{mM}$ Sodium Pyruvate (CellGro, Inc. "Va, USA") in distilled water. Cells were grown at $37^{\circ} \mathrm{C}$ in a humidified atmosphere containing $5 \% \mathrm{CO}_{2}$.

\subsection{Cytotoxicity assays}

Cells were seeded $(100 \mu \mathrm{L})$ into 96 -well microtiter plates and grown until they were approximately $70 \%$ confluent. The plates were then treated in the dark (to avoid photosensi- tized killing) with the appropriate concentration of $\mathrm{pz}$ or a volume of DMSO equivalent to the volume of compound added at these concentrations. Pz and DMSO solutions were added as $100 \mu \mathrm{L}$ aliquots to the original media in the well. The subsequent $200 \mu \mathrm{L}$ of media was thoroughly mixed, after which time $100 \mu \mathrm{L}$ was removed, resulting in a final volume of $100 \mu \mathrm{L}$ in each well; final pz/DMSO concentrations ranged from $50-1.56 \mu \mathrm{M}$. The media were removed at designated time points $(24,48,72,96$, or 120 hours), and $100 \mu \mathrm{L}$ of MTT/PBS solution was added to each well. The plates were then incubated for an additional 5 hours at $5 \% \mathrm{CO}_{2}$ and $37^{\circ} \mathrm{C}$. During this time, the tetrazolium ring of the MTT molecules is cleaved by the mitochondrial dehydrogenases of viable cells, resulting in the formation of purple formazan crystals. Following incubation, the supernatant was decanted, and $100 \mu \mathrm{L}$ of DMSO was added to each well to dissolve any formazan crystals. The absorbance was then read at $540 \mathrm{~nm}$ for each well. Each data point represents the average of at least four microtiter wells for each plate, and at least three independent trials were carried out for each experiment. Individual trials were normalized and averaged such that the final reported values represent a minimum of 12 independent values for each reported condition for each cell line.

\subsection{Phototoxicity assays}

Two identical 96-well plates were seeded with A549 and WI38 VA13 cells grown to $\sim 70 \%$ confluency as described above. The cells were then treated with the desired concentration of $\mathrm{pz}$ or $\mathrm{HpD}$ and incubated for additional 4 hours. Aluminum foil was then wrapped around the sides and top of the first plate, leaving the bottom of the plate uncovered in order to enable light penetration. The second plate was completely wrapped in aluminum foil to inhibit light from reaching the cells; this plate served as the dark control. The two plates were then placed on top of a standard X-ray illuminator (consisting of four $15 \mathrm{~W}$ bulbs, $\sim 3600$ total lumens) and exposed to 10 minutes of light. Following the light treatment, the plates were placed back into the incubator for 24 hours, after which time MTT cytotoxicity assays were performed.

\subsection{Imaging assays}

A549 and WI-38 VA13 cells were plated onto sterilized glass coverslips in $60 \times 15 \mathrm{~mm}$ dishes and grown at $37^{\circ} \mathrm{C}$ in a humidified atmosphere containing $5 \% \mathrm{CO}_{2}$. Upon reaching $60-80 \%$ confluency, the cells were treated with the desired $\mathrm{pz}$ at $25 \mu \mathrm{M}$ and incubated in the dark under the same conditions for an additional 4 hours. Negative controls were prepared by treating cells with an amount of DMSO equivalent to that of the $25 \mu \mathrm{M}$ pz sample.

Confocal microscopic images of the red pz emission were obtained at room temperature with a Zeiss 510 LSM confocal microscope. Following the 4-hour incubation period of the cells with the pz, the supernatant was decanted and the cells were washed twice with PBS. The washed coverslips were then inverted onto microscope slides, and the cells were imaged live in PBS. Cells were excited with an argon-ion laser 


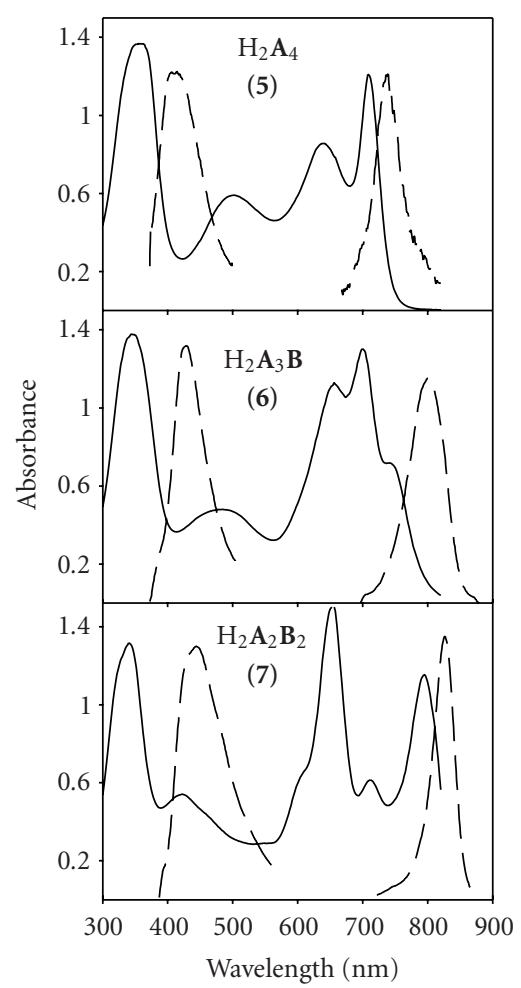

(a)

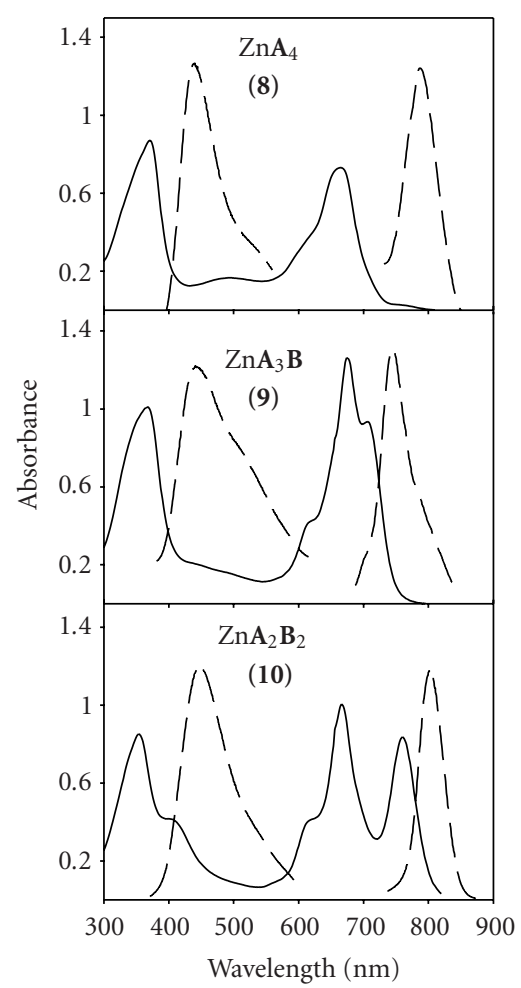

(b)

Figure 1: Absorbance (solid lines) and emission (dashed lines) spectra of $\mathrm{H}_{2}\left[\mathrm{pz}\left(\mathbf{A}_{n} \mathbf{B}_{4-n}\right)\right]$ and $\mathrm{Zn}\left[\mathrm{pz}\left(\mathbf{A}_{n} \mathbf{B}_{4-n}\right)\right] \mathrm{pzs}$ in $\mathrm{CH}_{2} \mathrm{Cl}_{2}$.

line at $488 \mathrm{~nm}$, and fluorescence was detected with a longpass $505 \mathrm{~nm}$ filter. All images were taken using the same detector gain and amplitude settings.

\section{RESULTS AND DISCUSSION}

\subsection{Pz synthesis and properties}

The six compounds examined in this study are of the form $\mathrm{M}\left[\mathrm{pz}\left(\mathbf{A}_{n} \mathbf{B}_{4-n}\right)\right]$, where $\mathrm{M}=\mathrm{H}_{2}$ or $\mathrm{Zn}$, A is $\left[\mathrm{S}\left(\left(\mathrm{CH}_{2}\right)_{2} \mathrm{O}\right)_{4} \mathrm{CH}_{3}\right]_{2}$, and $\mathbf{B}$ is a fused 4,7bis(isopropyloxy)benzo group, with $n=4(5,8), n=3$ (6, $9)$, and the trans form of $n=2(7,10)$. Scheme 1 shows the reaction scheme utilized to prepare the pzs.

In order to attach the desired tetra(ethylene glycol) monomethyl ether, $\left(\mathrm{CH}_{2} \mathrm{CH}_{2} \mathrm{O}\right)_{4} \mathrm{Me}$, functional group onto the periphery of a pz, it was first necessary to prepare 2-\{2-[2-(2-methoxyethoxy)ethoxy]ethoxy\}ethyl-4methylbenzenesulfonate (3) via tosylation of the commercially available tetra(ethylene glycol) monomethyl ether (2). MNT $\left[S\left(\mathrm{C}_{2} \mathrm{H}_{4} \mathrm{O}\right)_{4} \mathrm{Me}\right]_{2}$ (4) was then prepared by treating $\mathrm{Na}_{2}$ MNT with two equivalents of $\mathbf{3}$ in acetone at reflux for 12 hours.

Magnesium-templated Linstead macrocyclization [18] of

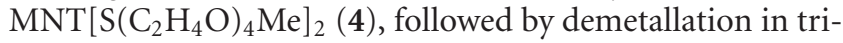
fluoroacetic acid and purification via column chromatography, led to the formation of the $\mathrm{H}_{2}\left[\mathrm{pz}\left(\mathbf{A}_{4}\right)\right], 5$, in $12 \%$ yield. The $\mathrm{H}_{2}\left[\mathrm{pz}\left(\mathbf{A}_{3} \mathbf{B}\right)\right](6,4 \%$ yield $)$ and trans $-\mathrm{H}_{2}\left[\mathrm{pz}\left(\mathbf{A}_{2} \mathbf{B}_{2}\right)\right](7$, $6 \%$ yield) pzs were prepared via a mixed cyclization of

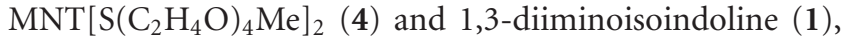
reacted in a $2: 1$ stoichiometric ratio, and followed by demetallation with trifluoroacetic acid. Column chromatography was then used to separate and purify the two compounds. It is noted that the cis $-\mathrm{H}_{2}\left[\mathrm{pz}\left(\mathbf{A}_{2} \mathbf{B}_{2}\right)\right]$ compound was not produced during this reaction, indicating that under these reaction conditions, the diiminoisoindoline (1) reacts preferentially with its cocyclization partner, 4 , resulting in only the trans form of the $\mathrm{M}\left[\mathrm{pz}\left(\mathbf{A}_{2} \mathbf{B}_{2}\right)\right]$. The yield of the transmacrocycle was further improved by the use of 0.38 equivalents of $\mathrm{Mg}$ per mole of combined cyclization partners, and by heating the reaction mixture for 7 hours at reflux in $n$ propanol. The corresponding zinc analogues $-8,9$, and $\mathbf{1 0}$ were prepared by reacting each of the free-base pzs in a solution of zinc chloride in $\mathrm{CHCl}_{3} / \mathrm{MeOH}$ at reflux for 30 minutes. All three compounds were obtained in quantitative yield.

Each compound is freely soluble in DMSO. By utilizing different combinations of $\mathrm{M}\left(\mathrm{H}_{2}\right.$ or $\left.\mathrm{Zn}\right)$ and $n(4,3$, or 2 , in a trans conformation), we can predictably vary the core macrocycle structure, resulting in different optical properties for each of the six pzs. Previous work has shown that the optical properties of the pzs are dependent upon $\mathrm{M}$ and $n$, but independent of $\mathrm{R}[10,11,19,20]$. Figure 1 shows typical spectra obtained in $\mathrm{CH}_{2} \mathrm{Cl}_{2}$ for the six pzs presented here. All six compounds exhibit an intense B (Soret) band at $\sim 350 \mathrm{~nm}$ with high extinctions $\left(\sim 50,000 \mathrm{M}^{-1} \mathrm{~cm}^{-1}\right)$, but each has a different $\mathrm{Q}$-band region, depending upon $\mathrm{M}$ and $n$. For the free-base pzs, split Q-bands are observed for both 
$\mathrm{MeO}\left(\mathrm{CH}_{2} \mathrm{CH}_{2} \mathrm{O}\right)_{4} \mathrm{H}$

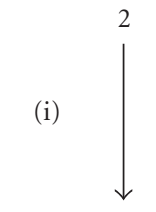

$\mathrm{MeO}\left(\mathrm{CH}_{2} \mathrm{CH}_{2} \mathrm{O}\right)_{4} \mathrm{Ts}$

3

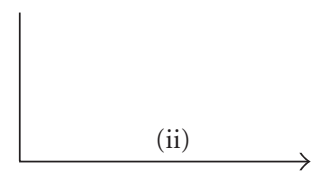

Y<smiles>N=C1NC(=N)c2c(Cl)ccc(O)c21</smiles>

$\mathrm{NH}$<smiles>CC(C)C</smiles>

1<smiles>CCOCCSC(C)=C(C#N)C#N</smiles>

4

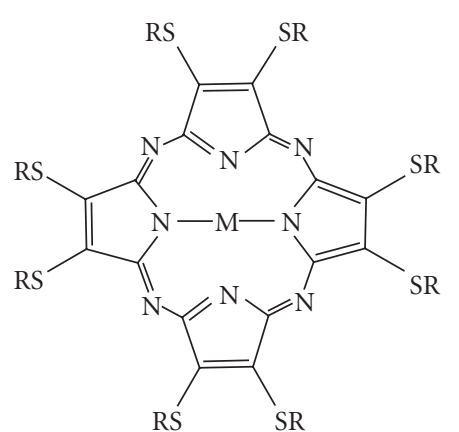

$\mathrm{M}\left[\mathrm{pz}\left(\mathbf{A}_{4}\right)\right]$

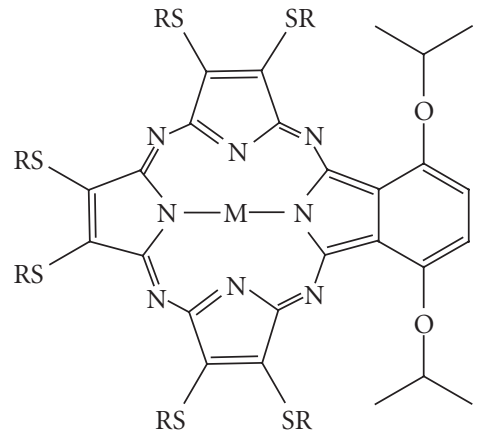

$\mathrm{M}\left[\mathrm{pz}\left(\mathbf{A}_{3} \mathbf{B}\right)\right]$

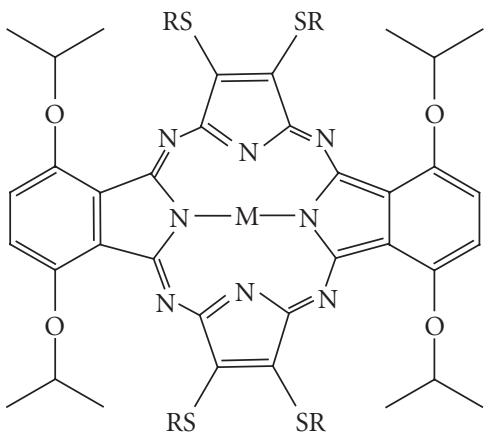

$\mathrm{M}\left[\mathrm{pz}\left(\mathbf{A}_{2} \mathbf{B}_{2}\right)\right]$

(v) $\left(\begin{array}{cc}5 & M=2 \mathrm{H} \\ 8 & M=Z n\end{array}\right.$

(v) $\left(\begin{array}{cc}6 & M=2 \mathrm{H} \\ 9 & M=Z n\end{array}\right.$

(v) $\left(\begin{array}{cc}7 & \mathrm{M}=2 \mathrm{H} \\ 10 & \mathrm{M}=\mathrm{Zn}\end{array}\right.$

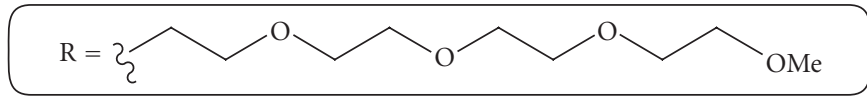

(i) $\mathrm{TsCl}, \mathrm{NaOH}, \mathrm{THF} / \mathrm{H}_{2} \mathrm{O}, \mathrm{RT}, 2 \mathrm{~h}$

(ii) $\mathrm{Na}_{2} \mathrm{MNT}$, acetone at reflux, $12 \mathrm{~h}$

(iii) $\mathrm{Mg}(\mathrm{OPr})_{2}, \mathrm{n}-\mathrm{PrOH}$ at reflux, $7 \mathrm{~h}$ (iv) TFA, $\mathrm{CH}_{2} \mathrm{Cl}_{2}, \mathrm{RT}, 1 \mathrm{~h}$

(v) $\mathrm{ZnCl}_{2}, \mathrm{CHCl}_{3} / \mathrm{MeOH}$, at reflux, $0.5 \mathrm{~h}$

Scheme 1: Synthetic route to porphyrazines 5-10. 


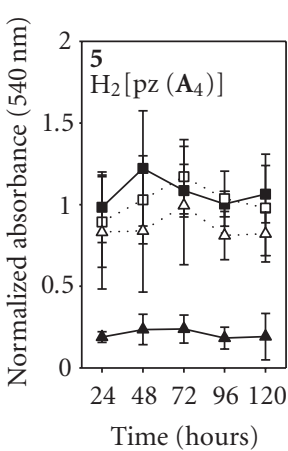

(a)

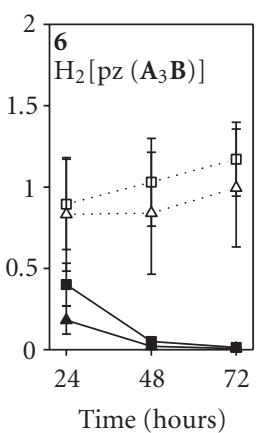

(b)

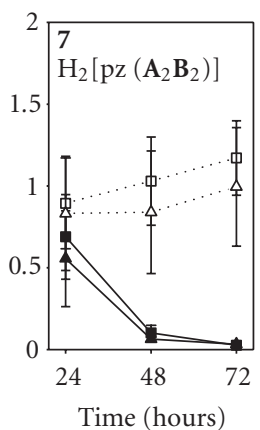

(c)

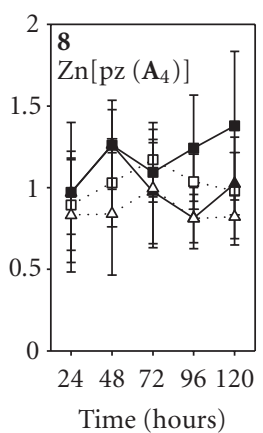

(d)

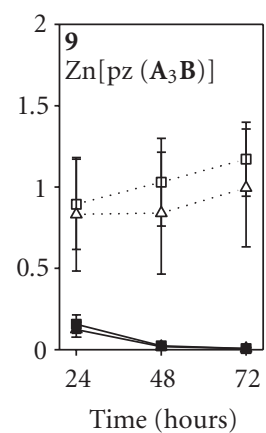

(e)

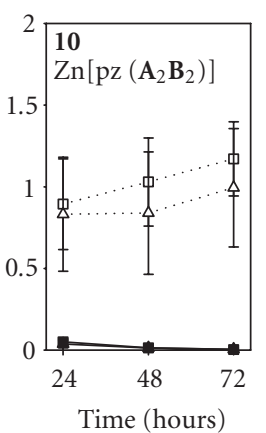

(f)

FIGURe 2: MTT time course plot of A549 $(\square)$ and WI-38 VA13 $(\Delta)$ cells exposed to $50 \mu \mathrm{M}$ pz. Dotted lines $=$ control $($ cells + DMSO), solid lines $=$ cells $+\mathrm{pz}$.

$n=3$ and $n=2$ (trans), with $\mathrm{H}_{2}\left[\mathrm{pz}\left(\mathbf{A}_{3} \mathbf{B}\right)\right]$ exhibiting a maximum absorption of $\sim 700 \mathrm{~nm}\left(\varepsilon \sim 45,000 \mathrm{M}^{-1} \mathrm{~cm}^{-1}\right)$ and $\mathrm{H}_{2}\left[\mathrm{pz}\left(\mathbf{A}_{2} \mathbf{B}_{2}\right)\right]$ having well-defined peaks at $\sim 654 \mathrm{~nm}$ and $798 \mathrm{~nm}\left(\varepsilon \sim 50,000 \mathrm{M}^{-1} \mathrm{~cm}^{-1}\right.$ for both), respectively; in contrast, the symmetrical $\mathrm{H}_{2}\left[\mathrm{pz}\left(\mathbf{A}_{4}\right)\right](n=4)$ exhibits only a single $\mathrm{Q}$-band with a maximum absorption at $\sim 712 \mathrm{~nm}$ $\left(\varepsilon \sim 35,000 \mathrm{M}^{-1} \mathrm{~cm}^{-1}\right)$. As expected, similar Q-band patterns are observed in the three $\mathrm{Zn}\left[\mathrm{pz}\left(\mathbf{A}_{n} \mathbf{B}_{4-n}\right)\right] \mathrm{pzs}$, but the peaks are shifted $\sim 30 \mathrm{~nm}$ towards the blue. $\mathrm{Zn}\left[\mathrm{pz}\left(\mathbf{A}_{4}\right)\right]$ has a single Q-band absorption at $672 \mathrm{~nm}\left(\varepsilon \sim 47,000 \mathrm{M}^{-1} \mathrm{~cm}^{-1}\right)$; both $\mathrm{Zn}\left[\mathrm{pz}\left(\mathbf{A}_{3} \mathbf{B}\right)\right]$ and $\mathrm{Zn}\left[\mathrm{pz}\left(\mathbf{A}_{2} \mathbf{B}_{2}\right)\right]$ have split Q-bands, with the former exhibiting a maximum absorption at $676 \mathrm{~nm}$ $\left(\varepsilon \sim 50,000 \mathrm{M}^{-1} \mathrm{~cm}^{-1}\right)$ and the latter having peaks at $666 \mathrm{~nm}$ $\left(\varepsilon \sim 54,000 \mathrm{M}^{-1} \mathrm{~cm}^{-1}\right)$ and $761 \mathrm{~nm}\left(\varepsilon \sim 45,000 \mathrm{M}^{-1} \mathrm{~cm}^{-1}\right)$, respectively. All six compounds also exhibit dual fluorescence, as shown in Figure 1: for the free-base pzs with $n=4,3$, and 2 , short wavelength (uv) fluorescence is observed at $\lambda_{\max }$ $=410,428$, and $440 \mathrm{~nm}$, respectively; and long wavelength (nir) fluorescence occurs at $\lambda_{\max }=737,800$, and $827 \mathrm{~nm}$, respectively; for the Zn pzs with $n=4$, 3, and 2, uv emission is observed at $\lambda_{\max }=435,444$, and $440 \mathrm{~nm}$, respectively; and nir emission occurs at $\lambda_{\max }=713,754$, and $795 \mathrm{~nm}$, respectively [10]. Both emissions can be generated with excitation wavelengths to the blue of $\sim 400 \mathrm{~nm}$, while only the nir luminescence is produced upon excitation to the red of $\sim 450 \mathrm{~nm}$. Unlike previously reported pzs in which broadening and aggregation were often observed $[15,16]$, the uv-visible spectra of 5-10 in DMSO looked nearly identical to the spectra obtained in $\mathrm{CH}_{2} \mathrm{Cl}_{2}$.

Earlier work with the pzs has also found that the singlet oxygen quantum yields $\left(\Phi_{\Delta}\right)$ for a series of $\mathrm{M}\left[\mathrm{pz}\left(\mathbf{A}_{n} \mathbf{B}_{4-n}\right)\right]$, where $\mathbf{A}=[S-R]_{2}$ and $\mathbf{B}$ is a fused dialkoxybenzo group, are dramatically affected by both $\mathrm{M}$ and $n$, but are independent of the identity of the R group [12]. For a given M, the quantum yield is found to increase as the value of $n$ is decreased. Therefore, the $\mathrm{H}_{2}\left[\mathrm{pz}\left(\mathbf{A}_{2} \mathbf{B}_{2}\right)\right]$, 7, has the highest quantum yield of the three free-base pzs $\left(\Phi_{\Delta} \sim 0.130\right)$, with $6\left(\Phi_{\Delta} \sim\right.$ $0.026)$ and $5\left(\Phi_{\Delta} \sim 0.0074\right)$ have markedly lower values. Introducing zinc into the core of the $\mathrm{pz}$ results in significantly higher yields than those found in the analogous free-base compounds. Thus the $\mathrm{Zn}\left[\mathrm{pz}\left(\mathbf{A}_{2} \mathbf{B}_{2}\right)\right], \mathbf{1 0}$, possesses the high- est singlet oxygen quantum yield $\left(\Phi_{\Delta} \sim 0.370\right)$ of the six compounds presented in this study, while the quantum yields for $\mathbf{9}\left(\Phi_{\Delta} \sim 0.110\right)$ and $\mathbf{8}\left(\Phi_{\Delta} \sim 0.037\right)$ are accordingly lower.

\subsection{Quantitative in vitro effect of porphyrazines}

MTT assays were used to test the proliferation/viability of A549 and WI-38 VA13 cells grown in the presence of compounds 5-10 over a 72-hour time period. Cells were initially treated with a pz concentration of $50 \mu \mathrm{M}$, and MTT assays were performed at 24, 48, and 72 hours (Figure 2).

In order to confirm that any toxicity observed was due to the pzs and not the DMSO solvent, control cells were exposed to a volume of DMSO equivalent to the volume of pzs at $50 \mu \mathrm{M}$; cells exposed to DMSO exhibited normal growth behavior. Unlike previously reported pzs which exhibited little cellular toxicity after a 24 -hour exposure $[15,16]$, four of the six pzs tested here exhibited marked toxicity to both normal and tumor cells within the first 24 hours upon $50 \mu \mathrm{M}$ exposure. (We note here that the $50 \mu \mathrm{M}$ treatment dose was chosen because it corresponds to the approximate amount of $\mathrm{HpD}$ typically needed to observe a clinical response in patients undergoing PDT treatments.) Cells grown in the presence of $\mathrm{H}_{2}\left[\mathrm{pz}\left(\mathbf{A}_{2} \mathbf{B}_{2}\right)\right], 7$, and the $\mathrm{M}\left[\mathrm{pz}\left(\mathbf{A}_{3} \mathbf{B}\right)\right]$ pzs, 6 $\left(\mathrm{M}=\mathrm{H}_{2}\right)$ and $9(\mathrm{M}=\mathrm{Zn})$, showed moderate-to-large decreases in viability after 24 hours, while cells treated with $\mathrm{Zn}\left[\mathrm{pz}\left(\mathbf{A}_{2} \mathbf{B}_{2}\right)\right], \mathbf{1 0}$, were almost completely killed within the first 24 hours of exposure. An additional 24 hours of exposure to pzs 6, 7, and 9 resulted in both normal and tumor cells being nearly completely killed.

The proliferation/viability of cells exposed to the $\mathrm{M}\left[\left(\mathbf{A}_{4}\right)\right]$ pzs, $5\left(\mathrm{M}=\mathrm{H}_{2}\right)$ and $\mathbf{8}(\mathrm{M}=\mathrm{Zn})$, contrasted sharply to that of the $\mathrm{M}\left[\mathrm{pz}\left(\mathbf{A}_{3} \mathbf{B}\right)\right]$ and $\mathrm{M}\left[\mathrm{pz}\left(\mathbf{A}_{2} \mathbf{B}_{2}\right)\right]$ pzs. Compound 8 showed little-to-no toxicity in either cell line over the entire time course of 72 hours, while 5 was found to be selectively toxic to normal cells. Nearly $80 \%$ of the WI-38 VA13 normal cells were killed within 24 hours upon exposure to 5, while no appreciable toxicity was seen for tumor cells exposed to 5 for 72 hours. The nontoxic behavior found with cells exposed to 5 (tumor only) and $\mathbf{8}$ (both tumor and normal) prompted the study of longer treatment times for these 
TABLE 1: Percent cell viability of various cell lines exposed to $50 \mu \mathrm{M} 5$ for 72 hours, relative to DMSO-treated cells.

\begin{tabular}{llr}
\hline Cell Line & Cell Line Description & Percent Cell Viability (\%) \\
\hline SCC016 & Human tongue squamous cell carcinoma & $91.2 \pm 19.2 \%$ \\
SCC040 & Human tongue squamous cell carcinoma & $95.3 \pm 23.8 \%$ \\
SCC056 & Human tongue squamous cell carcinoma & $94.8 \pm 20.5 \%$ \\
SCC114 & Human floor of mouth squamous cell carcinoma & $78.2 \pm 17.0 \%$ \\
SCC116 & Human alveolar ridge squamous cell carcinoma & $102.0 \pm 10.2 \%$ \\
BT-20 & Human breast adenocarcinoma & $118.4 \pm 4.5 \%$ \\
MCF-7 & Human breast adenocarcinoma & $77.7 \pm 19.6 \%$ \\
T-47D & Human breast adenocarcinoma & $106.4 \pm 8.4 \%$ \\
A549 & Human pulmonary adenocarcinoma & $92.7 \pm 23.6 \%$ \\
WI-38 VA13 & Human embryonic fibroblast & $20.9 \pm 23.3 \%$ \\
\hline
\end{tabular}

two compounds. Additional MTT assays were therefore carried out at 96 and 120 hours for both $\mathbf{5}$ and $\mathbf{8}$. However, as shown in Figure 2, these longer exposure times did not result in any additional observed toxicity.

The selective killing of the normal cells upon exposure to $\mathbf{5}$ prompted us to test this particular compound against other tumor cell lines to determine if the resistance of the A549 cells was consistent across different tumor cell lines and types. Table 1 shows the percent viability of human breast adenocarcinomas (BT-20, T-47D, and MCF-7) and human head and neck squamous cell carcinomas (SCC016, SCC040, SCC056, SCC114, and SCC116) exposed to 5 at $50 \mu \mathrm{M}$ for 72 hours, relative to DMSO-treated control cells. In general, very little toxicity was observed for any of the eight additional tumor cell lines, as growth rates of the pz-treated cells were similar to the growth rates of the DMSO-treated controls.

\subsection{Dose-dependent effects of porphyrazines}

As described above, exposure to the $\mathrm{M}\left[\mathrm{pz}\left(\mathbf{A}_{3} \mathbf{B}\right)\right]$ and $\mathrm{M}\left[\mathrm{pz}\left(\mathbf{A}_{2} \mathbf{B}_{2}\right)\right] \mathrm{pzs}$ at concentrations of $50 \mu \mathrm{M}$ resulted in significant toxicity in both tumor and normal cells (Figure 2). To determine the toxicity limits of each pz, MTT assays were carried out in both A549 tumor and WI-38 VA13 normal cells at varying concentrations $(1.56-50 \mu \mathrm{M})$ for 72 hours. Figure 3 shows the dose-dependent results as percent cell viability, calculated relative to the viability of the control DMSO-treated cells. (Note that treated cells growing at an equivalent rate to the DMSO control cells would have a $0 \%$ change in cell viability; treated cells which grew slower and/or were less viable than the control cells would have a negative percent change in cell viability.)

With the exception of the $\mathrm{M}\left[\mathrm{pz}\left(\mathbf{A}_{4}\right)\right] \mathrm{pzs}$, the thiotriethoxy(ethoxy)methyl-appended pzs were generally found to exhibit significant toxicity even at lower concentrations. Both of the $\mathrm{M}\left[\mathrm{pz}\left(\mathbf{A}_{2} \mathbf{B}_{2}\right)\right] \mathrm{pzs}, 7$ and $\mathbf{1 0}$, caused nearly $100 \%$ cell killing at treatment concentrations of $12.5 \mu \mathrm{M}$ and above. Significant toxicity was still observed for both tumor and normal cell lines exposed to $6.25 \mu \mathrm{M} \mathrm{10}$; however, A549 tumor cells exposed to 7 at $6.25 \mu \mathrm{M}$ showed only very little toxicity ( $\sim 10 \%$ killed), while normal cells exposed to the same concentration resulted in nearly $80 \%$ of the cells dying. Slight toxicity was still observed in both normal and tumor cells exposed to the lowest concentration of 10 tested $(1.56 \mu \mathrm{M})$, while normal and tumor cells exposed to 7 at a treatment concentration of $1.56 \mu \mathrm{M}$ showed essentially normal growth upon a 72-hour exposure.

While 7 and $\mathbf{1 0}$ showed a somewhat similar dosedependent proliferation/viability behavior, the two $\mathrm{M}\left[\mathrm{pz}\left(\mathbf{A}_{2} \mathbf{B}_{2}\right)\right]$ pzs, $\mathbf{6}$ and $\mathbf{9}$, differed depending upon the identity of $\mathrm{M}$. The $\mathrm{H}_{2}\left[\mathrm{pz}\left(\mathbf{A}_{3} \mathbf{B}\right)\right], \mathbf{6}$, was found to exhibit a growth behavior very similar to that observed for its $\mathrm{H}_{2}\left[\mathrm{pz}\left(\mathbf{A}_{2} \mathbf{B}_{2}\right)\right]$ analogue, 7. Significant toxicity was found in both tumor and normal cells exposed to $\mathbf{6}$ at concentrations of $12.5 \mu \mathrm{M}$ and above for 72 hours; and similar to 7 , the normal cells showed selective toxicity at treatment concentrations of $6.25 \mu \mathrm{M}$ and below. However, unlike cells exposed to 7 , normal cells treated with 6 at $1.56 \mu \mathrm{M}$ still exhibited a moderate amount of toxicity $(\sim 30 \%$ cell death $)$. The $\mathrm{Zn}\left[\mathrm{pz}\left(\mathbf{A}_{3} \mathbf{B}\right)\right]$ analogue, 9, showed significantly less toxicity at the higher treatment concentrations (25 and $12.5 \mu \mathrm{M})$ in both normal and tumor cells than that observed in cells treated with the free-base $\mathbf{6}$ at the same concentrations. However, slight toxicity $(\sim 10-20 \%$ cell killing) was still observed for both tumor and normal cells exposed to low concentrations of 9, whereas A549 tumor cells exposed to 6 at treatment concentrations of $6.25 \mu \mathrm{M}$ and below exhibited normal growth behavior.

Based upon the $50 \mu \mathrm{M}$ time-course plots in Figure 2, it was expected that the dose-dependence results of the $\mathrm{M}\left[\mathrm{pz}\left(\mathbf{A}_{4}\right)\right]$ pzs (Figure 3 ) would generally show little toxicity. To this end, the free-base 5 exhibited selective toxicity towards WI-38 VA13 cells at concentrations of $25 \mu \mathrm{M}$ and higher upon a 72-hour exposure; at treatment concentrations of $12.5 \mu \mathrm{M}$ and below, any toxicity observed in either the tumor or normal cells fell within the experimental error limits for normal growth (i.e., within the error range for a $0 \%$ change in cell viability). Both normal and tumor cells exposed to the $\mathrm{Zn}\left[\mathrm{pz}\left(\mathbf{A}_{4}\right)\right] \mathrm{pz}, \mathbf{8}$, also exhibited normal growth behavior at all concentrations studied.

\subsection{Photosensitizing effects of the porphyrazines}

In addition to the dark toxicity studies described above (Figures 2 and 3), light-dependent proliferation/viability studies were employed to determine if the compounds possessed 


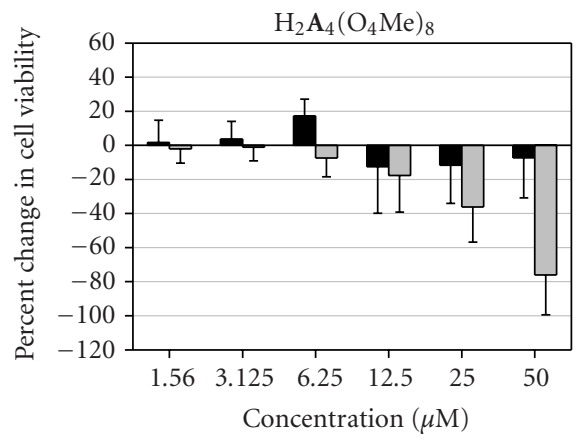

(a)

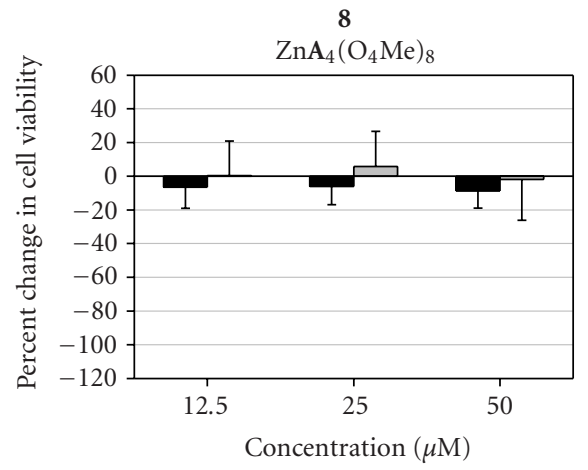

(d)
6

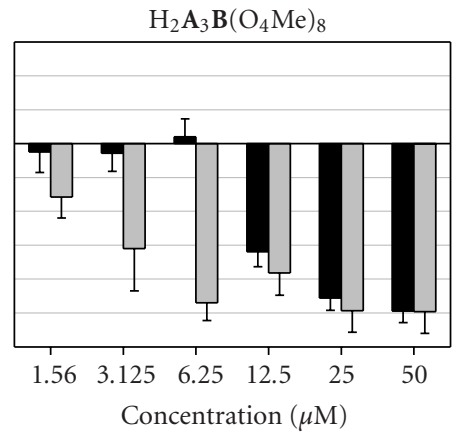

(b)

9

$\mathrm{ZnA}_{3} \mathbf{B}\left(\mathrm{O}_{4} \mathrm{Me}\right)_{8}$

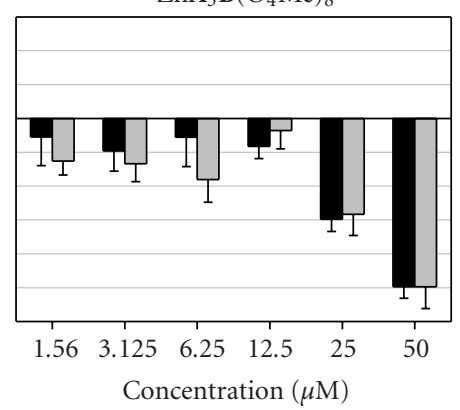

(e)

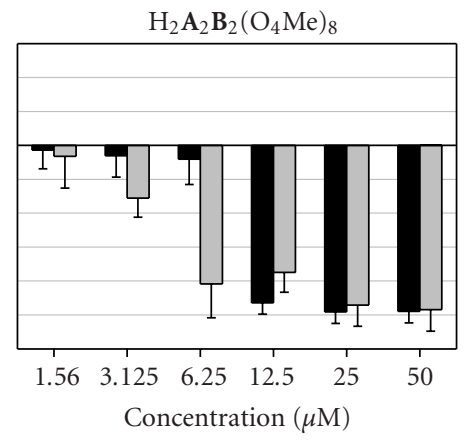

(c)

10

$\mathrm{ZnA}_{2} \mathbf{B}_{2}\left(\mathrm{O}_{4} \mathrm{Me}\right)_{8}$

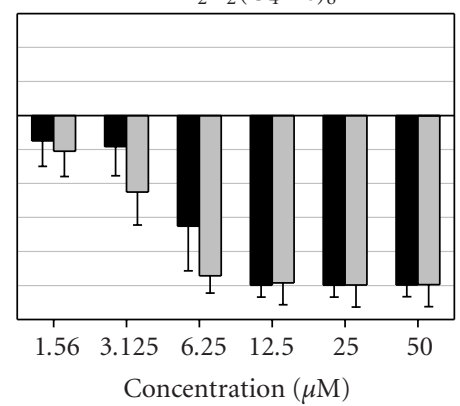

(f)

Figure 3: Percent cell viability, relative to DMSO control, of A549 (black bars) and WI-38 VA13 (gray bars) cells after a 72-hour exposure to pzs at varying concentrations. (Note that a $0 \%$ change in the percent cell viability correlates to cells which grew at the same rate as the control cells; negative values correlate to cells which grew at rates below those of the control cells.)

additional photosensitizing properties. Due to the high levels of toxicity observed in the MTT dose-dependence studies (Figure 3), a shorter incubation time and a lower treatment concentration were employed for these compounds than used in the biological studies of previously reported pzs $[15,16]$. Cell lines were treated with $25 \mu \mathrm{M}$ of $\mathbf{5 - 1 0}$ and 25 or $50 \mu \mathrm{M} \mathrm{HpD}$ as a reference for 4 hours and were then exposed to white light for a period of 10 minutes. The microtiter plate serving as the dark control was completely wrapped in aluminum foil so that the cells would avoid any light exposure, but would still be exposed to any potential heat being generated by the bulbs of the X-ray illuminator during the 10 minute treatment period. The cells were incubated overnight following the light treatment, and MTT assays were performed after 24 hours. Figure 4 shows data comparing no light treatment versus cells exposed to 10 minutes of white light.

Both untreated (data not shown) and DMSO-treated cells were used as controls; similar results were obtained for both; therefore, Figure 4 shows only the DMSO-treated cells.

As expected, growth of the DMSO-treated cells was not adversely affected by the additional light exposure. However, unlike previously studied pzs $[15,16]$, three of the compounds reported here-7, 9, and 10 - showed a distinct photosensitizing effect in the A549 tumor cells. It could not be determined if a similar effect occurred in the WI-38 VA13, due to the inherent toxicity of $7, \mathbf{9}$, and $\mathbf{1 0}$ in the normal cells; absorption readings at the 0 -minute light-exposure time point were extremely low for these three compounds in the WI-38 VA13 cell line (Figure 4). It is noted that, of the six pzs tested in this study, the three exhibiting the phototoxic effect in A549 cells correspond to the three compounds having the highest singlet oxygen quantum yield $\left(\Phi_{\Delta}\right)$. Accordingly, the compounds with relatively low $\Phi_{\Delta}$ values - $\mathbf{5}$, 6, and 8-did not show any appreciable phototoxic effect in either cell line, as viability levels remained steady with and without light treatment. Interestingly, no appreciable light effect was observed for either tumor or normal cells exposed to $25 \mu \mathrm{M} \mathrm{HpD}$ (a dose that is two-fold below the typical clinical treatment dose); however, treatment of cells with $\mathrm{HpD}$ at the usual clinical dose, $50 \mu \mathrm{M}$, results in substantial photoinduced cell death in both A549 and WI-38 VA13 cells, as shown in Figure 4.

Additional dose-dependent phototoxicity studies were carried out for 7, 9, and $\mathbf{1 0}$ in A549 cells to determine if a light-dependent response could be observed for the pzs below the $25 \mu \mathrm{M}$ treatment dose employed in Figure 4. Cells were treated with the pzs at concentrations of $25-1.56 \mu \mathrm{M}$ for 4 hours and then exposed to either 0 or 10 minutes of white light. MTT assays were carried out after an overnight incubation (Figure 5). As expected from the results of Figure 4, Photofrin did not show any light-induced toxicity 


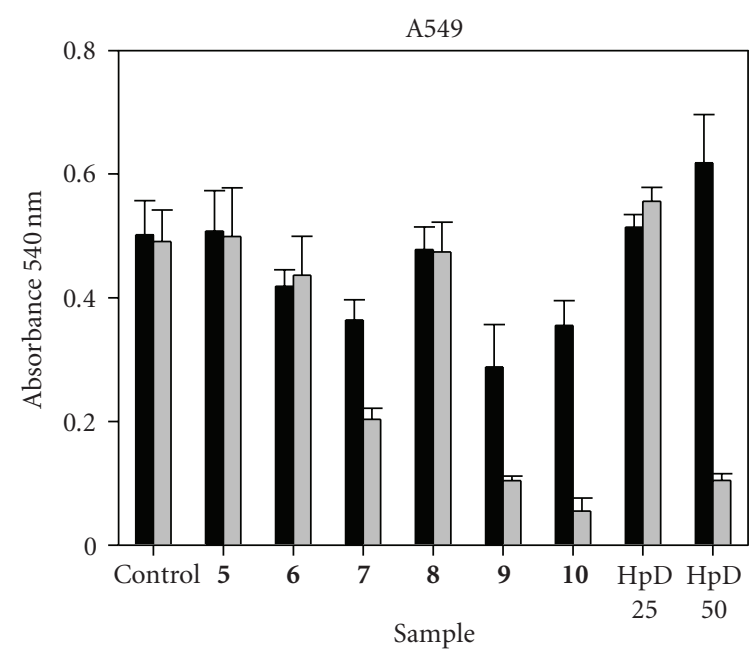

(a)

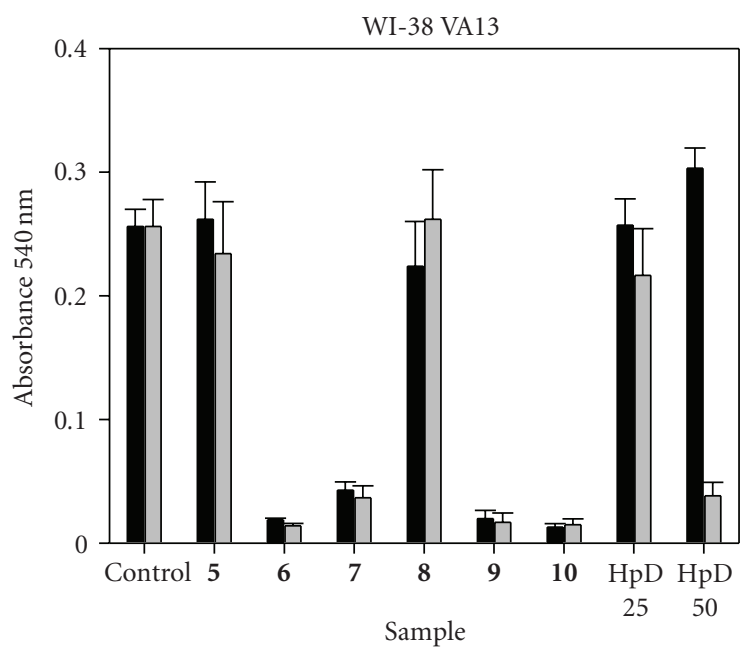

(b)

Figure 4: MTT results for A549 (a) and WI-38 VA13 (b) cells exposed to pz ( $25 \mu \mathrm{M}$ ) or HpD (25 or $50 \mu \mathrm{M})$ for 4 hours, followed by white light exposure for 0 (black bars) or 10 (gray bars) minutes. Control cells were treated with an amount of DMSO equivalent to $25 \mu \mathrm{M}$ pz.

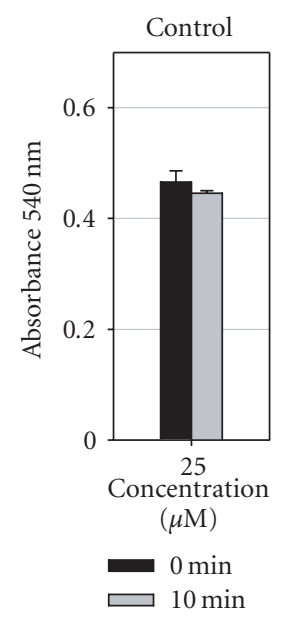

(a)

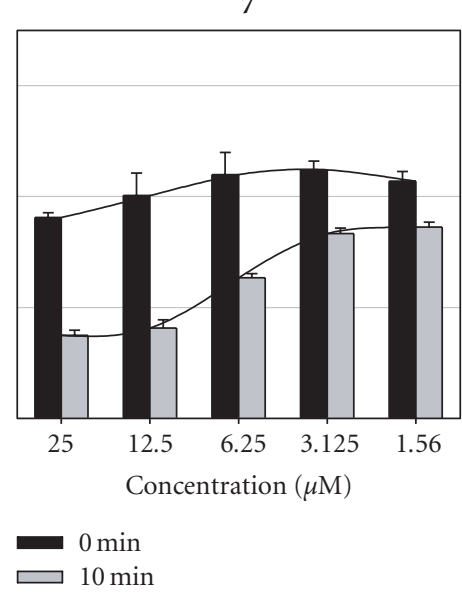

(b)
9

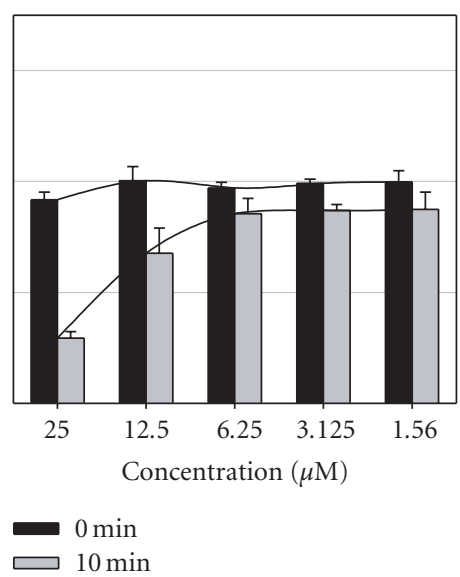

(c)

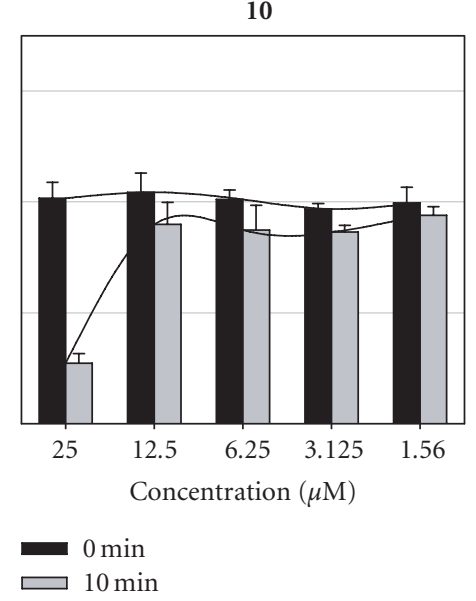

(d)

FIGURE 5: MTT results for A549 cells exposed to varying concentrations of pz or DMSO for 4 hours, followed by white light exposure for 0 (black bars) or 10 (gray bars) minutes. Line graphs are overlaid for clarity.

at treatment concentrations of $25 \mu \mathrm{M}$ or below (data not shown). However, significant phototoxicity was still observed in A549 cells treated with 7 at concentrations below $25 \mu \mathrm{M}$ upon a 10-minute white light exposure; a treatment dose of $12.5 \mu \mathrm{M}$ resulted in additional $60 \%$ of the cells being killed when exposed to light, while cells treated with $6.25 \mu \mathrm{M} 7 \mathrm{re}-$ sulted in approximately $40 \%$ cell death, relative to the dark toxicity (i.e., 0 minute white light exposure). Even at the lowest treatment concentration of 7 studied, $1.56 \mu \mathrm{M}$, a moderate amount ( $\sim 15-20 \%$ cell death) of toxicity was still observed. In contrast, both pzs $\mathbf{9}$ and $\mathbf{1 0}$ exhibited far less sensitivity than 7 . Moderate phototoxicity ( $\sim 30 \%$ cell death) was observed in A549 cells exposed to 9 at $12.5 \mu \mathrm{M}$, but little effect was detected at doses of $6.25 \mu \mathrm{M}$ and below. Cells treated with 10 did not show any additional phototoxicity at doses below $25 \mu \mathrm{M}$.

\subsection{Cellular uptake of porphyrazines}

Experiments were carried out to assess the cellular uptake and general localization behavior of each of the six pzs. Figure 6 presents the confocal microscopic images of A549 and WI-38 VA13 cells exposed to each compound for 4 hours at $25 \mu \mathrm{M}$. Due to the rapid onset of toxicity caused by these compounds, as discussed above, the cells were treated at a lower concentration and for a shorter period of time than the conditions used in previous cellular uptake studies of the pzs [15].

Moderate autofluorescence was observed for the control (DMSO-treated) cells in both tumor and normal samples. All six of the pzs showed enhanced intracellular luminescence in A549 cells upon treatment with compound; each of the six compounds displayed similar fluorescence intensity and 

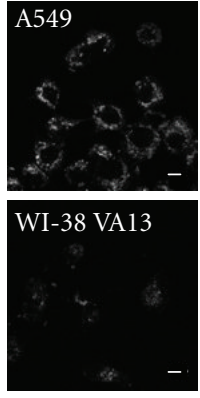

(a)
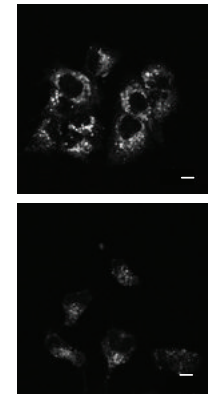

(b)
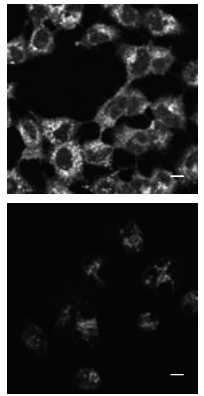

(c)
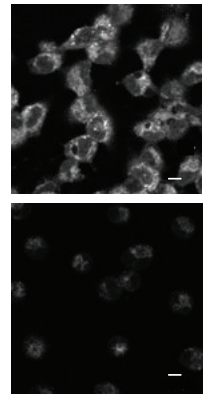

(d)

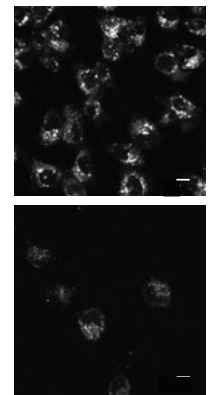

(e)

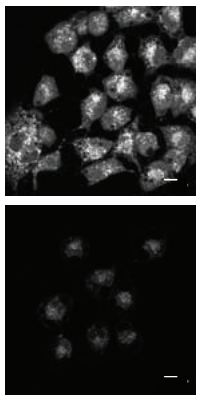

(f)

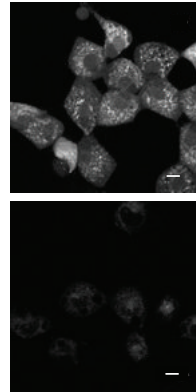

(g)

FIGURE 6: Cellular uptake of pzs using false-white confocal fluorescence microscopy images of A549 (top) and WI-38 VA13 (bottom) cells treated with $25 \mu \mathrm{M}$ agent: (a) DMSO control, (b) 5, (c) 6, (d) 7, (e) 8, (f) 9, (g) 10. Scale bar $=10 \mu \mathrm{m}$.

exhibited uniform staining of the cytoplasm with no uptake by the nucleus. In contrast, WI-38 VA13 cells showed littleto-no measurable increase in fluorescence upon treatment of the cells with the pzs. Significant vacuole formation was also observed in both tumor and normal cells exposed to 6, 9, and 10.

\section{CONCLUSIONS}

Recent work has sought to study the structure-function relationships of the porphyrazines (pzs) in biological systems, in an effort to develop these compounds for use as therapeutic and diagnostic agents $[15,16]$. Herein we continue our structure-function studies of the porphyrazines by examining a series of six new $\mathrm{M}\left[\mathrm{pz}\left(\mathbf{A}_{n} \mathbf{B}_{4-n}\right)\right]$ porphyrazines, where $\mathrm{M}=\mathrm{H}_{2}$ or $\mathrm{Zn}, \mathbf{A}$ is $\left[\mathrm{S}\left(\left(\mathrm{CH}_{2}\right)_{2} \mathrm{O}\right)_{4} \mathrm{CH}_{3}\right]_{2}, \mathbf{B}$ is a fused $4,7-$ bis(isopropyloxy)benzo group, and $n=2,3$, or 4 (Scheme 1). The thiotetra(ethylene glycol) monomethyl ether functional group is hydrophilic in nature, while the pz core is hydrophobic; thus for a given $\mathrm{M}$, as the value of $n$ is increased in the series, the resulting compounds progressively become more hydrophilic in character. Furthermore, by introducing zinc into the core of the pzs $(\mathbf{8}-\mathbf{1 0})$, the solubility of the compound and the singlet oxygen quantum yield are both enhanced, relative to their free-base analogues. The zinc pzs reported here are the first metallated pzs to be tested for their biological behavior. Concentration/time-dependent MTT proliferation/viability assays were carried out, both in the presence and absence of white light, in order to measure the dark and photoinduced toxicity of each pz in normal (WI-38 VA13) and tumor (A549) cell lines, and confocal microscopy was used to determine the cellular uptake and localization of each compound.

The dark toxicity studies of the six pzs revealed a dosedependent response in which cellular toxicity increased in both normal and tumor cell lines as $n$ was decreased (Figures 2 and 3 ). With the exception of $\mathbf{8}$, all of the pzs were found to be toxic to normal cells at higher concentrations $(25 \mu \mathrm{M}$ and above); and for the $\mathrm{M}\left[\mathrm{pz}\left(\mathbf{A}_{3} \mathbf{B}\right)\right]$ and $\mathrm{M}\left[\mathrm{pz}\left(\mathbf{A}_{2} \mathbf{B}_{2}\right)\right] \mathrm{pzs}$, significant toxicity was also observed in the tumor cells at higher concentrations. In general, for a given concentration, the observed toxicity was found to be greater in the normal cells than in the tumor cells. Furthermore, in the case of the $\mathrm{M}\left[\mathrm{pz}\left(\mathbf{A}_{3} \mathbf{B}\right)\right]$ and $\mathrm{M}\left[\mathrm{pz}\left(\mathbf{A}_{2} \mathbf{B}_{2}\right)\right]$ pzs, for a given $n$, toxicity was generally found to be higher for the free-base compounds than for the metallated pzs.

A particularly interesting result from the dark toxicity studies is the finding that $\mathbf{5}$ is selectively toxic to normal cells. As shown in Figure 2 and Table 1, 5 was found to be nontoxic across a number of different tumor cell lines and tumor types (both adenocarcinomas and squamous cell carcinomas), suggesting that this compound might possess multiple uses as a diagnostic agent. First, when attempting to establish a cell line derived from a human tumor (for purposes of preparing a cell line that will grow continuously in the laboratory), it is necessary to selectively remove and purify the tumor cells from the tumor sample removed from the patient, which contains a mixture of normal and cancerous tissue. This procedure is often very difficult and timeconsuming; if $\mathbf{5}$ were added during this process, one could theoretically remove the normal cells more quickly, leading to faster purification of the desired tumor cell line. Second, the results of many patient biopsies are unclear as to whether a particular tissue sample is malignant or benign; in such unclear cases, one could treat the biopsy sample with $\mathbf{5}$ to verify the malignancy of the tissue.

The photo-induced toxicity studies (Figure 4) found further toxicity in A549 cells exposed to the pzs with higher singlet oxygen quantum yields-7, 9, and 10. These three compounds are the first members of the $\mathrm{M}\left[\mathrm{pz}\left(\mathbf{A}_{n} \mathbf{B}_{4-n}\right)\right]$ subclass to exhibit photosensitivity $[15,16]$. The result for 7 is particularly interesting, considering that previously studied $\mathrm{H}_{2}\left[\mathrm{pz}\left(\mathbf{A}_{2} \mathbf{B}_{2}\right)\right]$ pzs all contained $\mathbf{A}$ groups that resulted in aggregation of the compound in aqueous media, thereby suppressing singlet oxygen generation. The result observed here suggests that we have achieved the proper hydrophobic/hydrophilic balance necessary for sufficient solubility in cellular environments, and this enhanced solubility is likely a key contributing factor in the observed photosensitivity of $\mathbf{7}$ at relatively low doses (Figure 5). Furthermore, the observation that $6\left(\mathrm{H}_{2} \mathrm{~A}_{3} \mathrm{~B}\right)$ did not exhibit a light-dependent toxicity, while $\mathbf{9}\left(\mathrm{ZnA}_{3} \mathrm{~B}\right)$ did show a response, suggests that the inherent singlet oxygen quantum yield of the free-base $\mathrm{A}_{3} \mathrm{~B}$ structure may not be high enough to be applicable in PDT 
applications. Likewise, no photo-induced toxicity was observed for the $\mathrm{M}\left[\mathrm{pz}\left(\mathbf{A}_{4}\right)\right]$ pzs, $\mathbf{5}$ and $\mathbf{8}$, regardless of the identity of $\mathrm{M}$. Therefore, the development of future pzs for PDT applications will focus mainly on members of the $\mathrm{A}_{2} \mathrm{~B}_{2}$ (both free-base and metallated) and metallated $\mathrm{A}_{3} \mathrm{~B}$ subfamilies. However, while members of the $\mathrm{M}\left[\mathrm{pz}\left(\mathbf{A}_{4}\right)\right]$ and $\mathrm{H}_{2}\left[\mathrm{pz}\left(\mathbf{A}_{3} \mathbf{B}\right)\right]$ pz subfamilies may not provide any additional PDT activity, it is still important to study pzs belonging to these subfamilies in an effort to discover new selectively toxic antitumor agents.

Confocal fluorescence microscopy images revealed that all six of the compounds prepared in this study were preferentially incorporated into the A549 tumor cells and localized in the cytoplasm. The results of the cellular uptake studies further suggest that $\mathbf{8}$ is a particularly promising imaging agent since it was found to be nontoxic upon exposure to both tumor and normal cells and was selectively taken up by tumor cells. As mentioned above, vacuole formation was observed in both the tumor and normal cells upon exposure to 6,9 , and 10 , suggesting that these compounds may be inducing terminal differentiation, a specialized form of apoptosis $[21,22]$. Future work will more closely examine the mechanism by which the pzs in this report $(5-7,9,10)$ cause cell death. By determining the role of the pzs in cell destruction, we may be able to slightly alter the structure of the compounds in order to minimize toxicity (while maintaining the proper pz solubility and selective tumor uptake), thus leading to many other potential imaging agents from this class of compounds.

The results of this study are the first steps in the search for useful tumor specific imaging agents and compounds for use in purifying cell lines from clinical samples. If the issue of nonselective toxicity can be overcome, the path to developing porphyrazines as useful antitumor drugs (both traditional and PDT-activated) will be opened up.

\section{ACKNOWLEDGMENTS}

This work was supported by the NIH (CA 88850) and by the Illinois Department of Public Health (76280040, 76280042). Its contents are solely the responsibility of the authors and do not necessarily reflect the official views of the NIH or the Illinois Department of Public Health.

\section{REFERENCES}

[1] R. K. Pandey and G. Zheng, "Porphyrins as photosensitizers in photodynamic therapy," in The Porphyrin Handbook, K. M. Kadish, K. M. Smith, and R. Guilard, Eds., vol. 6, pp. 157-230, Academic Press, San Diego, Calif, USA, 2000.

[2] D. Wöhrle, A. Hirth, T. Bogdahn-Rai, G. Schnurpfeil, and M. Shopova, "Photodynamic therapy of cancer: second and third generations of photosensitizers," Russian Chemical Bulletin, vol. 47, no. 5, pp. 807-816, 1998.

[3] T. J. Dougherty, "Photodynamic therapy (PDT) of malignant tumors," Critical Reviews in Oncology/Hematology, vol. 2, no. 2, pp. 83-116, 1984.

[4] F. M. Little, C. J. Gomer, S. Hyman, and M. L. J. Apuzzo, “Observations in studies of quantitative kinetics of tritium labelled hematoporphyrin derivatives $\left(\mathrm{H}_{\mathrm{p}} \mathrm{D}_{\mathrm{I}}\right.$ and $\left.\mathrm{H}_{\mathrm{p}} \mathrm{D}_{\mathrm{II}}\right)$ in the normal and neoplastic rat brain model," Journal of Neuro-Oncology, vol. 2, no. 4, pp. 361-370, 1984.

[5] R. K. Pandoy, "Synthetic strategies in designing porphyrinbased photosensitizers for photodynamic therapy," in CRC Handbook of Organic Photochemistry and Photobiology, W. Horspool and F. Lenci, Eds., pp. 144-1-144-21, CRC Press, Boca Raton, Fla, USA, 2nd edition, 2004.

[6] C. M. Allen, W. M. Sharman, and J. E. Van Lier, "Current status of phthalocyanines in the photodynamic therapy of cancer," Journal of Porphyrins and Phthalocyanines, vol. 5, no. 2, pp. 161-169, 2001.

[7] R. K. Chowdhary, I. Shariff, and D. Dolphin, "Drug release characteristics of lipid based benzoporphyrin derivative," Journal of Pharmacy and Pharmaceutical Sciences, vol. 6, no. 1, pp. 13-19, 2003.

[8] J. L. Sessler and D. Seidel, "Synthetic expanded porphyrin chemistry," Angewandte Chemie International Edition, vol. 42, no. 42 , pp. 5134-5175, 2003.

[9] D. Kessel and T. J. Dougherty, "Agents used in photodynamic therapy," Reviews in Contemporary Pharmacotherapy, vol. 10, no. 1, pp. 19-24, 1999.

[10] S. L. J. Michel, B. M. Hoffman, S. M. Baum, and A. G. M. Barrett, "Peripherally functionalized porphyrazines: novel metallomacrocycles with broad, untapped potential," in Progress in Inorganic Chemistry, vol. 50, pp. 473-590, John Wiley \& Sons, New York, NY, USA, 2001.

[11] S. Lee, A. J. P. White, D. J. Williams, A. G. M. Barrett, and B. M. Hoffman, "Synthesis of near-IR absorbing/emitting porphyrazine derivatives with tunable solubility," Journal of Organic Chemistry, vol. 66, no. 2, pp. 461-465, 2001.

[12] S. Lee, R. Stackow, C. S. Foote, A. G. M. Barrett, and B. M. Hoffman, "Tuning the singlet oxygen quantum yield of nearIR-absorbing porphyrazines," Photochemistry and Photobiology, vol. 77, no. 1, pp. 18-21, 2003.

[13] E. G. Sakellariou, A. G. Montalban, H. G. Meunier, et al., "Peripherally metalated secoporphyrazines: a new generation of photoactive pigments," Inorganic Chemistry, vol. 41, no. 8, pp. 2182-2187, 2002.

[14] E. G. Sakellariou, A. G. Montalban, S. L. Beall, et al., "Novel peripherally functionalized seco-porphyrazines: synthesis, characterization and spectroscopic evaluation," Tetrahedron, vol. 59, no. 46, pp. 9083-9090, 2003.

[15] N. D. Hammer, S. Lee, B. J. Vesper, et al., "Charge dependence of cellular uptake and selective antitumor activity of porphyrazines," Journal of Medicinal Chemistry, vol. 48, no. 26, pp. 8125-8133, 2005.

[16] B. J. Vesper, S. Lee, N. D. Hammer, et al., "Developing a structure-function relationship for anionic porphyrazines exhibiting selective anti-tumor activity," Journal of Photochemistry and Photobiology B, vol. 82, no. 3, pp. 180-186, 2006.

[17] A. Davison, R. H. Holm, R. E. Benson, and W. Mahler, "Metal complexes derived from cis-1,2-dicyano-1,2ethylenedithiolate and bis(trifluoromethyl)-1,2-dithiete," in Inorganic Syntheses, vol. 10, pp. 8-26, McGraw-Hill, New York, NY, USA, 1967.

[18] R. P. Linstead and M. J. Whalley, "944. Conjugated macrocycles-part XXII: tetrazaaporphyrin and its metallic derivatives," Journal of Chemical Society, pp. 4839-4846, 1952.

[19] T. P. Forsyth, D. B. G. Williams, A. G. Montalban, C. L. Stern, A. G. M. Barrett, and B. M. Hoffman, "A facile and regioselective synthesis of trans-heterofunctionalized porphyrazine derivatives," Journal of Organic Chemistry, vol. 63, no. 2, pp. 331-336, 1998. 
[20] C. S. Velázquez, G. A. Fox, W. E. Broderick, et al., "Starporphyrazines: synthetic, structural, and spectral investigation of complexes of the polynucleating porphyrazineoctathiolato ligand," Journal of the American Chemical Society, vol. 114, no. 19, pp. 7416-7424, 1992.

[21] Y. Capetanaki, S. Smith, and J. P. Heath, "Overexpression of the vimentin gene in transgenic mice inhibits normal lens cell differentiation," The Journal of Cell Biology, vol. 109, no. 4, pp. 1653-1664, 1989.

[22] C. E. Gagna, H.-R. Kuo, E. Florea, et al., "Comparison of apoptosis and terminal differentiation: the mammalian aging process," Journal of Histochemistry and Cytochemistry, vol. 49, no. 7, pp. 929-930, 2001. 